TITLE:

\title{
NEW SPECIES OF MOLLUSCS FROM THE AMAKUSA MARINE BIOLOGICAL LABORATORY, REIHOKU-CHO, AMAKUSA, KUMAMOTO PREF., JAPAN
}

\section{$\operatorname{AUTHOR}(\mathrm{S}):$}

Habe, Tadashige

\section{CITATION:}

Habe, Tadashige. NEW SPECIES OF MOLLUSCS FROM THE AMAKUSA MARINE BIOLOGICAL LABORATORY, REIHOKU-CHO, AMAKUSA, KUMAMOTO PREF., JAPAN. PUBLICATIONS OF THE SETO MARINE BIOLOGICAL LABORATORY 1960, 8(2): 289-298

\section{ISSUE DATE:}

1960-12-20

URL:

http://hdl.handle.net/2433/174651

RIGHT: 


\title{
NEW SPECIES OF MOLLUSCS FROM THE AMAKUSA MARINE BIOLOGICAL LABORATORY, REIHOKU-CHO, AMAKUSA, KUMAMOTO PREF., JAPAN ${ }^{1)}$
}

\author{
TADASHIGE HABE \\ Amakusa Marine Biological Laboratory \\ (Kyushu University), Reihoku-cho, Amakusa \\ With 5 Text-figures
}

During the biological survey of the sea around Tomioka Peninsula, Amakusa, we have collected more than 921 molluscan species as listed in Part. 1. Mollusca of the Fauna and Flora of the Sea around the Amakusa Marine Biological Laboratory edited by the writer and Mr. T. KIKUCHI in 1960, in which more than sixteen species are new to science. While some had been reported already in two other papers, most of them have never been described elsewhere. Therefore, the writer has given the descriptions for these species in the following lines.

\section{Pteria (Austropteria) dendronephthya sp. nov. (Pteriidae)}

Shell rather small for the genus, light yellow to brownish black, sometimes clouded by the black blotches along the growth lines or reddish radial rays, oblique. Left valve larger and more inflated than the right. Posterior wing extends backwards, forming the rather shallow posterior sinuation. Anterior winged area rather small, triangular, pointed to the anterior end and covered with the rough periostracum, on which prickly cords radiate from the umbo. In the right valve antero-ventral margin has a byssal incurvation from which the byssus comes out. The median area rather smooth, large and elongated postero-ventrally.

Length $28.5 \mathrm{~mm}$, height $16.3 \mathrm{~mm}$, and breadth $9.3 \mathrm{~mm}$ (conjoined valves) (type specimen)

Length $29.5 \mathrm{~mm}$, height $19.2 \mathrm{~mm}$ and breadth $8.5 \mathrm{~mm}$ (conjoined valves paratype specimen)

Length $26.0 \mathrm{~mm}$, height $14.0 \mathrm{~mm}$ and breadth $7.3 \mathrm{~mm}$ (conjoined valves) (paratype specimen)

1) Contributions from the Amakusa Marine Biological Laboratory (Kyushu University), No. 137.

Publ. Seto Mar. Biol. Lab., VIII (2), 1960. (Article 20) 
Length $27.8 \mathrm{~mm}$, height $16.9 \mathrm{~mm}$ and breadth $9.2 \mathrm{~mm}$. (conjoined valves) (paratype specimen)

Length $21.2 \mathrm{~mm}$, height $12.4 \mathrm{~mm}$ and breadth $5.7 \mathrm{~mm}$ (conjoined valves) (paratype specimen)

Type locality: Tomioka, Amakusa, Kumamoto Pref.

Distribution: Tanabe Bay, Wakayama Pref. (collected by Mr. T. Yamamoto).

Remarks: This new species commonly attaches to the species of Dendronephthya, D. castanea UTINOMI and its allied forms, by the byssus as in the other pterid species at Tomioka, Amakusa. This differs from the allied forms P. brevialata (Dunker), $P$. cypsellus (Dunker) and $P$. loveni (Dunker), which are also collected from the same locality, in having the shell not exceeded $30 \mathrm{~mm}$ in length even in the adult form, with a short posterior wing, the end of which is shorter than the posterior end of the median area of the shell. The habitat of this species is also unique in attaching to soft alcyonarians.

\section{Joannisiella nomurai sp. nov. (Ungulinidae)}

Diplodonta semiaspera Yokoyama (non Philippi) had been renamed as $D$. semiasperoides by Nomura in 1932. But D. semiaspera YoKoyama of 1922 is not the same as D. aspera YoKoyAma of 1920 and does not belong to this genus as an unnamed species of the genus Joannisiella. Therefore, the writer gives a new name $J$. nomurai for the species of 1922 .

Shell white, rather thin, inflated, orbicular, somewhat concaved at the anterior dorsal margin. Surface with the growth lines only. Hinge plate with one solid anterior and one bifurcate posterior cardinal in the right valve and one bifurcate anterior and one solid posterior cardinals in the left.

Type locality: Tomioka, Amakusa, Kumamoto Pref.

Length $18.5 \mathrm{~mm}$, height $16.3 \mathrm{~mm}$ and breadth $5.2 \mathrm{~mm}$. (right valve) (type specimen)

Length $23.1 \mathrm{~mm}$, height $20.5 \mathrm{~mm}$ and breadth $6.6 \mathrm{~mm}$ (left valve) (paratype specimen)

Length $16.4 \mathrm{~mm}$, height $14.5 \mathrm{~mm}$ and breadth $4.4 \mathrm{~mm}$ (right valve) (paratype specimen)

Distribution: Issiki, Aichi Pref. (collected by Mr. S. Hayashi).

Remarks: The shell of this new species is less inflated and thicker than other Joannisiellid species of Japan, except a small species $J$. tsuchii Yамамото et НАBE.

\section{Hyalokellia polita gen. et sp. nov. (Erycinidae)}

Shell small, thin, polished and translucent, ovate, the anterior area being shorter than the posterior which is widely produced. Umbo small, clined forwards and one-third from the anterior end. Hinge plate thin and narrow. Right valve 
with a small anterior cardinal, a long posterior lateral tooth and a resilifer pit between them. Left valve with a very weak anterior cardinal tooth and a thin, narrow posterior lateral tooth to be fixed a groove between the posterior lateral tooth and posterior dorsal margin in the right valve.

Length $5.1 \mathrm{~mm}$, height $3.3 \mathrm{~mm}$ and breadth $0.8 \mathrm{~mm}$ (right valve) (type specimen)

Length $5.8 \mathrm{~mm}$, height $3.8 \mathrm{~mm}$ and breadth $0.9 \mathrm{~mm}$ (left valve) (paratype specimen)

Type locality: Tomioka, Amakusa, Kumamoto Pref.

Remarks: This new species has the very thin bean-shaped shell with the thin hinge plate on which an anterior cardinal tooth and a posterior lateral tooth apart from the cardinal appear in each valve. By these features this species is proposed a new genus Hyalokellia, differing from the genus Kellia in lacking the distinct posterior cardinal tooth in each valve. The species of the genus Fronsella has the shell strongly produced anteriorly with a short but distinct posterior lateral tooth.

4. Melliteryx puncticulata flexuosa subsp. nov. (Ërycinidae)

(Figs. 4 et 5 )

This subspecies is characterized by the flexures at both antero- and posteroventral areas, differing from the original species. Therefore a subspecific name flexuosa is proposed for this interesting form.

Length $7.3 \mathrm{~mm}$, height $4.3 \mathrm{~mm}$ and breadth $1.3 \mathrm{~mm}$ (right valve) (type specimen figured)

Type locality: Obama Bay, Fukui Pref.

Distribution: Tomioka, Amakusa, Kumamoto Pref.

Remarks: Only one imperfect specimen has been collected from off the west coast of Tomioka.

\section{Callista pilsbryi sp. nov. (Veneridae)}

Shell small for the genus, solid, moderately inflated, ovate, somewhat attenuate behind, dull white, usually blotched with purplish brown in a more or less radiating of zigzag manner. Lunule lanceolate, bordering by a distinct groove. Hinge armature as in Callist chinensis (HoLteN).

Length $10.7 \mathrm{~mm}$, height $7.8 \mathrm{~mm}$ and breadth $4.8 \mathrm{~mm}$ (conjoined valves) (type specimen)

Length $9.0 \mathrm{~mm}$, heigth $6.5 \mathrm{~mm}$ and breadth $3.5 \mathrm{~mm}$ (conjoined valves) (paratype specimen)

Length $11.3 \mathrm{~mm}$, height $8.0 \mathrm{~mm}$ and breadth $2.4 \mathrm{~mm}$ (right valve) (paratype specimen) 
Length $17.5 \mathrm{~mm}$, height $12.3 \mathrm{~mm}$ and breadth $7.0 \mathrm{~mm}$ (conjoined valves) (specimen from Isshiki, Aichi Pref.)

Type locality: Tomioka, Amakusa, Kumamoto Pref.

Distribution: West coast of Kyushu, Shikoku, and Pacific coast of Honshu.

Remarks: This is rather common on the sandy bottom of $5-20 \mathrm{~m}$ in depth at Tomioka, Amakusa. The specimens from Hirado, Nagasaki Pref. near Amakusa were identified as Callista roscida Gould from Ousima (=Amami Oshima), but the writer had examined the specimen named by GoulD, which had been deposited in the U. S. National Museum finding that this specimen was a young shell of Callista chinensis (Holten). Therefore, a new name should be eastablished for this species as Callista pilsbryi. The specimens from Amami-Oshima which have been confused with this species, this species also differs in having the more inflated shell with more prominent umbo and with the thick hinge plate. A new name Callista amamiensis is proposed for these specimens, the type specimen of which measures $13.3 \mathrm{~mm}$ in length by $9.8 \mathrm{~mm}$ in height by $6.8 \mathrm{~mm}$ in breadth in the conjoined valves. Another specimen measures $11.3 \mathrm{~mm}$ in length by $8.5 \mathrm{~mm}$ in height by $6.0 \mathrm{~mm}$ in breadth in the conjoined valves.

\section{Cadella narutoensis sp. nov. (Tellinidae)}

(Fig. 1)

Shell rather large for the genus, solid, white, sometimes light orange, ovate, rounded posteriorly and attenuate anteriorly forming the larger anterior area; Umbo situated one-third of the length of the shell from the posterior end, somewhat prominent and inclined backwards. Anterior dorsal margin slightly curved and ventral margin gently curved. Surface with regularly marked growth lines. External ligament distinctly present behind the umbo. In the right valve only two cardinal teeth appeared, the larger triangular anterior one of which is bifurcate and in the right valve two cardinal teeth, the posterior triangular one of which is bifurcate and anterior and posterior lamellate lateral teeth, the anterior of which being longer. The grooves between the dorsal margin and the lateral tooth are fixed with the dorsal margin of the left valve.

Length $15.0 \mathrm{~mm}$, height $10.3 \mathrm{~mm}$ and breadth $3.0 \mathrm{~mm}$ (left valve) (type specimen)

Length $17.4 \mathrm{~mm}$, height $12.0 \mathrm{~mm}$ and breadth $3.5 \mathrm{~mm}$ (right valve) (paratype specimen from Shirahama, Wakayama Pref.)

Length $16.2 \mathrm{~mm}$, height $11.3 \mathrm{~mm}$ and breadth $2.8 \mathrm{~mm}$ (right valve) (paratype specimen from Shirahama)

Length $13.5 \mathrm{~mm}$, height $8.7 \mathrm{~mm}$ and breadth $5.0 \mathrm{~mm}$ (conjoined valves) (paratype specimen from Tomioka)

Length $14.7 \mathrm{~mm}$, height $9.0 \mathrm{~mm}$ and breadth $2.6 \mathrm{~mm}$ (left valve) (paratype specimen from Ariake Sea) 
Type locality: Naruto, between Tokushima Pref., Shikoku and Awaji Island, Hyogo Pref., Honshu.

Distribution: Kyushu, Shikoku and Wakayama Pref., Honshu.

Remarks: This is very close to C. mauia DALL, BARTSCH and ReHDer from Hawaii, but has the larger shell with the more roundly produced anterior margin and less elongated to the posterior margin. Cadella lubrica (Gould) from the northern Japan has the shell with the straight anterior dorsal margin and coloured in orange rose.

\section{Myadoropsis dissimilis gen. et sp. nov. (Myochamidae)}

Shell white, rather solid, flat, inequivalve, the right valve being slightly flatter than the left, and the former tightly embracing the latter, elongately oblong, inequilateral. The anterior side rounded at the end and the posterior somewhat obliquely truncated. Umbo about two-fifths from the posterior end. Lunule and escatcheon distinct and lanceolate. In the left valve anterior dorsal margin slightly convex and the posterior dorsal straight. Ventral margin also almost straight. In the right valve the slightly excavated posterior dorsal margin forms a right angle at the postero-dorsal corner of the obliquely truncated posterior margin. Surface with the lines of growth and a weak flexure from the umbo to the postero-ventral corner. Interior of the left valve with a small alivincular resilifer pit below the small umbo in clined backwards, as a small sinuation of the dorsal margin and a small tooth-like knob on the postero-dorsal margin just behind the umbo and a deep sinuation to half way of the mantle line from the posterior end.

Length $9.3 \mathrm{~mm}$, height $5.7 \mathrm{~mm}$ and breadth $1.5 \mathrm{~mm}$ (left valve) (type specimen)

Length $8.5 \mathrm{~mm}$, height $5.0 \mathrm{~mm}$ and breadth $1.3 \mathrm{~mm}$ (left valve) (paratype specimen)

Length $6.3 \mathrm{~mm}$, height $3.5 \mathrm{~mm}$ and breadth $1.7 \mathrm{~mm}$ (conjoined valves) (paratype specimen)

Type locality: The west coast of Tomioka, Amakusa, Kumamoto Pref.

Remarks: This new species is close to Myadoropsis transmontana (YoKoуAMA) which is formerly known as a species of the genus Thraciopsis in the family Thracidae, but now should be transferred to this new genus of the family Myochamidae in having the alivincular resilifer, not the parivincular. A new genus Myadoropsis is proposed for these two species and an Australian species Myadora elongat a MAY, among them $M$. transmontana being the type species, in having the shell with a deep mantle sinus, two distinct cardinal tooth-like knobs below the umbo in the right valve and somewhat inflated in both valves. This species is easily distinguished from $M$. transmontana in having the higher shell, the umbo of which is not sharply angulate and not curved backwards. 


\section{Siphonodentalium japonicum sp. nov. (Siphonodentaliidae)}

Shell small, glossy, milky white, moderately curved and regularly attenuate to the top on which four notches appeared. The anterior one is the broadest and other three are deeply sinuated.

Length $6.0 \mathrm{~mm}$, breadth at the mouth $0.8 \mathrm{~mm}$ and breadth at the top $0.4 \mathrm{~mm}$ (type specimen)

Length $5.7 \mathrm{~mm}$, breadth $0.8 \mathrm{~mm}$ at the mouth and breadth at the top $0.4 \mathrm{~mm}$ (paratype specimen)

Type locality: Tomioka, Amakusa, Kumamoto Pref.

Remarks: This new species is rather common on the fine sandy bottom of about $40 \mathrm{~m}$ in depth off the west coast of Tomioka, Amakusa. Hitherto the writer had described two species of this genus from Japan. Compared with these two species, $S$. okudai and $S$. isaotakii, this is the smallest species among them.

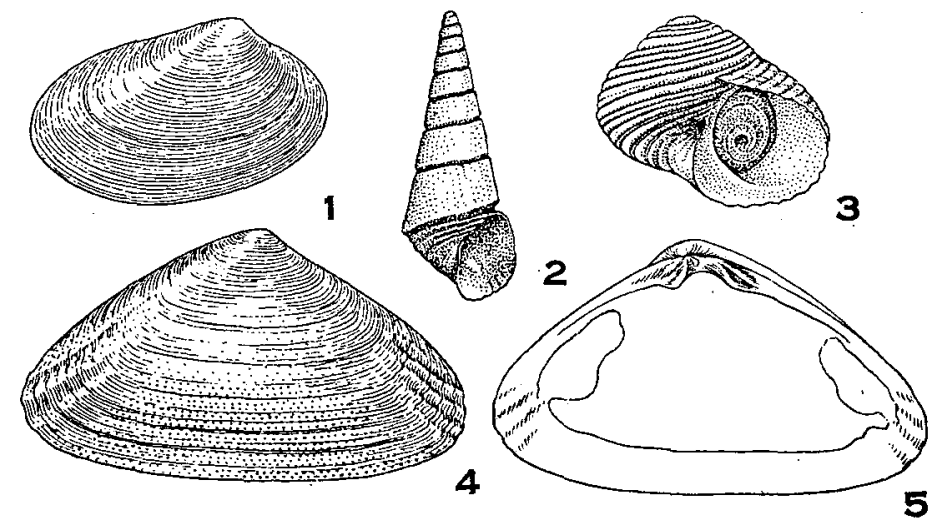

Fig. 1. Cadella narutoensis sp. nov. (left valve) $\times 1.5,2$. Diala stricta sp. nov. $\times 4,3$. Collonista amakusaensis sp. nov. $\times 5,4,5$. Melliteryx punctulata flexuosa subsp. nov. (right valve) $\times 5$.

\section{Laetifautor elegans sp. nov. (Trochidae)}

Shell small, conical, imperforate, brown fawn with yellowish blotches arranged radially and present six in number on the body whorl. Whorls 7 in number, two of which are the smooth protoconch. Body whorl with three strongly lamellate spiral cords between the suture and the somewhat lamellate peripheral cord, the top of cord is distinctly crenulated like a gear by the pale yellowish short spines, and with seven spiral narrow cords on the flat base coloured in brown and pale yellow alternately. Aperture subquadrate in shape. Peristome thin except the thick columellar margin, forming an angular corner at the lower end.

Length $6.8 \mathrm{~mm}$ and breadth $6.4 \mathrm{~mm}$ (type specimen)

Type locality: Tomioka, Amakusa, Kumamoto Pref.

Remarks: Laetifautor rubropunctatum (A. ADAMs) is an allied species to this 
new species, but has the taller conic shell on which the spiral cords are more prickle and the intervals of these spiral cords are crossed by the stout axial cords, forming deep pits.

\section{Collonista amakusaensis sp. nov. (Turbinidae)}

(Fig. 3)

Shell small, white, solid, umbilicate, globose. Whorls about $4 \frac{1}{2}$ in number. Body whorl large, with about 20 spiral cords rather regularly arranged and a space between two cords as wide as each one cord, which are crossed by the growth lines. Penultimate whorl has 5-6 spiral cords. Aperture circular and peristome continuous. Outer and basal margins well rounded and columellar margin very thick and widen below, forming a wide callus area. Umbilical border somewhat crenulated. Operculum calcareous, paucispiral, spirally sculptured outside, the nucleus of which deeply sinks.

Length $4.3 \mathrm{~mm}$ and breadth $3.8 \mathrm{~mm}$ (type specimen)

Length $4.0 \mathrm{~mm}$ and breadth $3.6 \mathrm{~mm}$ (paratype specimen)

Length $3.8 \mathrm{~mm}$ and breadth $3.5 \mathrm{~mm}$ (paratype specimen)

Type locality: Tomioka, Amakusa, Kumamoto Pref.

Distribution: Yakushima and Tanegashima, both south of Kyushu.

Remarks: This is very common on the gravelly shore at Tomioka. Collonista glareosa GoulD which is very close to this species, has many rose patches and more numerous spiral cords on the shell.

\section{Barleeia trifasciata sp. nov. (Rissoidae)}

Shell minute, rather solid, ovate conic, coloured in light brown with three darker bands encircled on the body whorl, the first band beneath the suture, the second above the periphery and the broadest third on the base and they become paler in colour to the aperture. Body whorl about two thirds of the entire shell length and obtusely angulate on the periphery. Umbilicus closed. Aperture ovate and peristome continuous. Outer margin gently curved and the basal rounded. The columellar short, slightly oblique and thickened. On the parietal wall the columellar and outer margins are connected with the thin callus. Operculum with a distinct process on the inner margin.

Length $2.0 \mathrm{~mm}$ and breadth $1.1 \mathrm{~mm}$ (type specimen)

Length $1.8 \mathrm{~mm}$ and breadth $1.0 \mathrm{~mm}$ (paratype specimen)

Length $1.8 \mathrm{~mm}$ and breadth $1.0 \mathrm{~mm}$ (paratype specimen)

Type locality: Tomioka, Amakusa, Kumamoto Pref.

Remarks: This minute species is very common on the sea weeds in the tide pools on the rocky shore. This is not a young stage of a certain species and is allocated in the genus Barleeia in having the unique operculum. 


\section{Diala stricta sp. nov. (Cerithiidae)}

(Fig. 2)

This species is very close to Diala varia A. ADAMs which is the type species of this genus, but is easily distinguished from the latter in having the larger conic shell with the straight lateral sides and with the canaliculated suture and six grooves on the base of the body whorl.

Length $6.0 \mathrm{~mm}$ and breadth $2.2 \mathrm{~mm}$ (type specimen figured)

Length $5.5 \mathrm{~mm}$ and breadth $2.1 \mathrm{~mm}$ (paratype specimen)

Length $4.8 \mathrm{~mm}$ and breadth $1.7 \mathrm{~mm}$ (paratype specimen)

Length $6.7 \mathrm{~mm}$ and breadth $2.4 \mathrm{~mm}$ (specimen from Tomioka)

Type locality: Minamata, Kumomoto Pref. (collected by Dr. T. Kuroda).

Distribution: Tomioka, Amakusa, Kumamoto Pref., Tanabe Bay, Wakayama Pref. and Hamanako, Shizuoka Pref.

\section{Cerithiopsis spongicola sp. nov. (Cerithiopsidae)}

Shell small, elongated conic, light chestnut brown. Whorls 10 in number two of which are the smooth protoconch. Body whorl two fifths of the entire length of the shell. Each whorl sculptured with about 35-40 axial ribs which are crossed by three incised spiral grooves between the suture and the peripheral groove. The interval between two axial ribs as wide as a rib and are crossed by many transverse narrow cords. The base of the body whorl with weak spiral cords. Aperture ovate, decidedly with a short anterior canal. Outer margin thin and columellar margin short and twisted. Parietal wall covered with a thin callus.

Length $6.3 \mathrm{~mm}$ and breadth $2.6 \mathrm{~mm}$ (type specimen)

Length $7.8 \mathrm{~mm}$ and breadth $3.0 \mathrm{~mm}$ (paratype specimen)

Type locality: Tomioka, Amakusa, Kumamoto Pref.

Distribution: Yura Bay, Wakayama Pref. and Isshiki, Aichi Pref. (collected by Mr. S. HAYASHI).

Remarks: This is rather commonly commensal with a sponge attached to the spindle shell, Fusinus ferrugineus KURODA et HABE, at Tomioka and somewhat relates to Cerithiopsis stejnegeri DALL of the North Pacific in the sculpture of the shell, but the axial ribs on the shell of this species are about $35-40$ in number instead of 26 in that species on the body whorl.

\section{Reticunassa praematurata KURODA et HABE (sp. nov.) (Nassariidae)}

Shell small, thin, elongated ovate, light brown with a paler zone above the periphery and a paler broad zone on the base of the whorl. Whorls $6 \frac{1}{2}$ in number, two of which are the smooth protoconch. Except the last one or one and half whorls, others have about $12-18$ axial ribs and 4-5 spiral cords which are crossed 
by the axials, forming the weak nodules on them. On the last 1-1: whorls the axials are reduced away to the aperture and spiral cords of about 10-12 in number are still distinct. Aperture semilunate. Outer margin rounded, producing downwards and slightly expanded. Columellar margin strongly twisted at the lower end forming a short canal. No denticles on the interior of the aperture and the parietal wall covered with a thin callus.

Length $4.8 \mathrm{~mm}$ and breadth $2.7 \mathrm{~mm}$ (type specimen)

Length $4.7 \mathrm{~mm}$ and breadth $2.7 \mathrm{~mm}$ (paratype specimen)

Length $4.5 \mathrm{~mm}$ and breadth $2.6 \mathrm{~mm}$ (paratype specimen)

Length $5.4 \mathrm{~mm}$ and breadth $3.0 \mathrm{~mm}$ (paratype specimen)

Type locality: Tomioka, Amakusa, Kumamoto Pref.

Distribution: Akune, Kagoshima Pref. and the Inland Sea of Japan.

Remarks: This species is very characteristic by the very thin shell, on the body whorl of which the axial ribs are reduced away.

\section{Reticunassa chibi sp. nov. (Nassariidae)}

Shell small, solid, ovate, reddish brown with a yellowish zone above the periphery. Whorls $6 \frac{1}{2}$ in number, of which $1 \frac{1}{2}$ whorls are the smooth protoconch. Succeeding whorls with three narrow spiral cords and about 10 stout axial ribs and the penultimate with 3-4 spiral cords and 12-13 axial ribs. Body whorl with about 15-17 axials and 10 spirals, forming the risings on the axials. Aperture small, ovate, peristome continuous by the parietal callus, on the upper part of which one notch is present. Outer margin thick, forming a varix outside and 4-6 denticles within, of which the basal four are stout.

Length $6.7 \mathrm{~mm}$ and breadth $4.0 \mathrm{~mm}$ (type specimen)

Length $6.8 \mathrm{~mm}$ and breadth $4.4 \mathrm{~mm}$ (paratype specimen)

Length $6.4 \mathrm{~mm}$ and breadth $3.9 \mathrm{~mm}$ (paratype specimen)

Type locality: Tomioka, Amakusa, Kumamoto Pref.

Remarks: This somewhat relates to $R$. acutidendata (Sмітн), but the shell of the former is quite small, not exceed $7 \mathrm{~mm}$ in length and haven't the granulated sculpture on the surface of the shell. This is very common on the fine sandy mud bottom of about $10 \mathrm{~m}$ in depth in Tomioka Bay.

\section{Zafra validicosta sp. nov. (Columbellidae)}

Shell small, fusiform, rather solid, pale yellow, some times with a brown band on the periphery of the upper whorls and with the darker anterior canal. Whorls 7 in number, the body whorl about half the length of the shell. Surface with strong costae which are reduced away at near the aperture and on the base of the body whorl. Number of costae about 15 on the penultimate whorl. Aperture elongate. Outer, margin thin and rather straight. Columellar margin thickened 
and erect apart from the whorl, straight downwards and twisted at the lower end, forming the canal.

Length $5.3 \mathrm{~mm}$ and breadth $2.0 \mathrm{~mm}$ (type specimen)

Length $5.0 \mathrm{~mm}$ and breadth $2.0 \mathrm{~mm}$ (paratype specimen)

Length $5.0 \mathrm{~mm}$ and breadth $2.0 \mathrm{~mm}$ (paratype specimen)

Type locality: Tomioka, Amakusa, Kumamoto Pref.

Remarks: This species is close to Zafra mitraeformis A. Adams which is also known as Zafra vitrea (SMITH) and Z. zonata (Gould) and has the larger shell with the stouter but less numerous costae on the surface. 